\title{
The zinc isotope composition of late \\ Holocene open-ocean marine sediments
}

\section{ALEX DICKSON}

Royal Holloway, University of London

Presenting Author: alex.dickson@rhul.ac.uk

Existing constraints on the isotopic composition of $\mathrm{Zn}$ burial in the modern ocean are based on a handful of studies from marine locations characterised by either intense organic matter accumulation (e.g. the Californian and Mexican margins) or intense oxygen depletion (e.g. the Cariaco Basin and Black Sea). New $\mathrm{Zn}$ isotope data have been collected from a globally distributed array of late-Holocene age sediments that accumulated in the open ocean in upwelling zones (Namibian margin, West African margin, Arabian margin, Californian margin, Peruvian margin) and in deep-marine non-upwelling zones (Southern Ocean, Indian Ocean, North and South Atlantic Oceans, South China Sea). The mean authigenic isotopic composition of $\mathrm{Zn}$ in the entire dataset is only slightly lower than modern deep-ocean water $(\sim 0.50 \%$ ). Upwelling zones have greater authigenic enrichments of $\mathrm{Zn}$ and higher $\mathrm{Zn}$ isotope compositions than non-upwelling sites although the uncertainties of the latter overlap. The amount of $\mathrm{Zn}$ in the investigated sediments cannot be fully accounted for by organic matter burial (using $\mathrm{Zn} / \mathrm{C}$ ratios) or oxyhydroxide burial (using $\mathrm{Zn} / \mathrm{Fe}$ and $\mathrm{Zn} / \mathrm{Mn}$ ratios) and the burial of $\mathrm{ZnS}$ may therefore be required to balance the sedimentary $\mathrm{Zn}$ budget, even in non-upwelling settings. The new data indicate that open-ocean marine sediments track the deep-ocean $\mathrm{Zn}$ isotope composition to within $0.1-0.2$ $\%$, except in areas where isotopically distinct $\mathrm{Zn}$ fractions dominate the authigenic $\mathrm{Zn}$ budget. 